\title{
Covid-19 impact on the Entrepreneurial practices in Small startups
}

\author{
Eydaros Misky ${ }^{1}$, Sultan Alzahrani ${ }^{1}$, and Mowffaq Oreijah ${ }^{1,2}$ \\ ${ }^{1}$ Institute of Innovation and Entrepreneurship, Umm Al-Qurra University, Saudi Arabia \\ ${ }^{2}$ Mechanical Engineering Dept., College of Engineering, Umm Al-Qura University,
}

Saudi Arabia

January 2021

Email: Eydaros@hotmail.com

\begin{abstract}
:
COVID-19 has disrupted the global economy and the pandemic impact on businesses has been devastating. The majority of the enterprises suffered the lockdown consequences and the entrepreneurial small startups have been the most to struggle from the pandemic impacts such as financial deficiency, drop in sales, loss of customers, and shut down permanently. Due to their lack of skills and experience, they couldn't diversify their product sources and distribution. On the other hand, some small startups have gained huge profits due to the pandemic which included online commercials for sanitizers and masks, and some specialize in food and beverage products. This paper research reviews the impact and the survival strategies for entrepreneurial small startups during the ongoing crisis of COVID-19. A review of the literature includes reviewing all the relevant scientific published data and an included case study represents a practical example that highlights the impact of COVID-19 on the small enterprises.
\end{abstract}

Keywords: COVID-19, small startups, Entrepreneurship, crises. 


\section{INTRODUCTION}

Covid-19 continues to hinder the global economy and population movements around the world, as more than a billion people around the world are affected from various aspects, whether economic, social and political. In an attempt to stop the spread of this virus, it is found that students from all over the Arab countries have returned to their homes, most companies have directed their employees to work from home, and flights have stopped the majority of their journeys.

The global financial markets have suffered trillions of dollars in losses due to the uncertainty, and it was demonstrated that emerging companies are likely to suffer the most, thus a great effort must be devoted within all countries in order to support them.

Startups are likely be affected particularly strongly as they find themselves in a fragile state, being sensitive to disruptions in demand, supply, or credit conditions. Statistics show that in the last week of March, new business applications were down by $40 \%$ compared to the same week one year earlier, a contraction that is even sharper than that during the Great Recession (Haltiwanger, 2016).

Governments and decision-makers should re-evaluate the measures that were taken and work to amend them to re-work in the various economic sectors, formulate new policies for tax and customs exemption, and develop new policies regarding the problem of paying checks. All in an attempt to deal with the apparent change in customer behavior and the flexibility to adapt to rapidly changing situations.

Concerns about the future of these companies need deep planning. As it was seen in recent days, the repercussions of the virus have increased, especially in the economic sphere which led to tightened financial conditions, banks' doubts raised about the ability of consumers and companies to repay loans on time. 
Many companies declared complete bankruptcy due to the virus, as well as some employees.

The topic raises a set of questions related to the relationship of the continuation or suspension of these small companies and the crisis and repercussions of Corona-19 around the world.

- How does the virus affect entrepreneurial practices in startups?

- What is the future of these small companies and their entrepreneurship after the crisis?

- What are the most important solutions available to them in order to come out with the least losses?

Small start-up companies are the first victim of most of the nations that the world has known since the concept of the global economy began. The reason is that it in the first stage of the beginning of its operational work. It is often funded initially by its pioneering founders in an attempt to benefit from the development of a product or service they believe is required. Given limited revenues or high costs, and in return unprecedented challenges and difficulties emerged for all startups, especially since startups are the least capable of facing entities, at least in terms of material capabilities, or business experiences that can be based on them in making the appropriate decisions to overcome The difficulties that almost fail the entities, and even countries, where the virus COVID-19 crisis during its short life, which did not exceed a few weeks, caused a reduction in the demand for all products, which affected the returns of these projects in their early life as well as the disruption of the necessary supplies of supplies Production, especially that obtained from international sources, with restrictions imposed on travel and global trade. The difficulties faced by startups were not limited to this extent. 
A report on the "Covid-19" crisis, which will pose real challenges to startups around the world, said that despite the obstacles and losses occurring in this crisis. However, the situation has become an opportunity for some startups to demonstrate the viability of their technologies and were able to multiply their profits by providing products that contribute to reducing the impact of the crisis on their customers or meeting their needs remotely.

It is worth noting is that the establishment of these startups again and rebuilding the foundation of those that have been damaged and did not come out safe from the crisis depends on support and nothing else.

Hence, great efforts are required to address the long-term impact of the crisis by adopting an organized approach that helps everyone in the workforce to overcome these new realities that will impose themselves in the labor market. Given the scale of the crisis left by the spread of Covid-19, the workforce needs information and studies on the nature of this impact on various sectors and jobs, and to obtain guidance and training on the steps they need to take to ensure a promising and successful career.

The aim of this study is to enhance a scholarly understanding of how small businesses and entrepreneurs are affected by this Crisis and why the small businesses are the first affected in this crisis.

\section{Methodology}

An exploratory methodology was adopted with high literature review. The research included scientific journals, review researches, case studies, policy documents, research papers, and reports which are relevant to the current research study. This paper research study will implement the cross-sectional design. 
This is based on the view of entrepreneurial small startups owners are included in this study in order to have a generalized perspective regarding the impact of COVID-19 on their businesses.

The applied method involves observational data and information gathered from the participation in the population. The process of data collection will be conducted using online questionnaires through different social media platforms that will be distributed to the participants and invite them to participate in the online survey.

The questionnaire includes 16 main questions are that require ten minutes completing. The approximate number of employees suggested for answering the questionnaire is 3 entrepreneurs of small and micro firms and enterprises.

The questions used in the study were majorly closed to ensure that specific data was obtained from the analysis of respondent's data, especially with a focus impact of COVID-19 on their businesses.

The types of questions used in the questionnaire are: Demographic, Likert and Text questions. Demographic questions such as experience, gender, nationality or age assists in analyzing their answers. Linkert scale questionnaires convert complex opinion to simple ones thus allowing for better comprehension. They help in testing to measure beliefs, attitudes and opinion of the entrepreneurs. Using these types of questions makes it easy to draw conclusions, reports, results and graphs from the responses.

Open end questions which are considered a secondary analysis tool which allow entrepreneurs to give more detailed information, such as feelings, attitudes and understanding of the subject. This allows for better access to the entrepreneur's true feelings on how the pandemic affected their business.

Checklists allows the identification of the factors that mostly would assist in surviving the pandemic. Once the answers are collected, they are sent for analysis. 
The questionnaire is involved obtaining permission from the relevant authorities through email to use the questions and made a few modifications to suit this research.

Finally, this study considers the importance of ethics and legal requirements for the study since it involves human subjects as the participants. The ethical and legal requirement was met whereby the questionnaire has a consent form. The participants are required to read the consent form and sign it after understanding the whole reason for the research and reading the information about how the information will be used.

\section{Case study}

A case study that was conducted by interviewing the top managers of a wholesale and retail firm located in Macau. Companies were selected based on the size of the organization and whether they have experienced a significant impact from the current COVID-19 outbreak. (Alves et al, 2019)

The selected firm was set up two years ago by two young local entrepreneurs who sold badminton rackets and supplies, sports equipment and sportswear.

During COVID19 crisis, the firm has recorded significant loss of customers and number of sales due to panic that occurred in the community in addition to the massive and temporary shutdown of badminton courts by government order. The owner estimated that the organization's total financial loss was around USD 12,500.

Currently the firm is struggling with crisis management plan and strategy but with narrow focus, mainly due to limitation of resources and absence of a sense of crisis planning. The firm has a contingency plan as well, which includes purchasing from numerous suppliers and increase product diversification.

During the outbreak, the firm decreased the hours of operation, cut down non-essential operating expenditure, and decreased inventories. 
It also boosted promotion on social media and offered additional $15 \%$ discounts and sales during the crisis. The firm is introducing new sports equipment for home use as well.

As for resilience strategies, the firm is planning to increase promotion through social media, provide discounts, and implement products. It also considers applying for the new small enterprises loan for the COVID-19 crisis provided by the government of Macau.

Finally, the owner mentioned that the firm size would make a difference in industry as small firms suffer a less economic loss due to low inventory levels, rental burden and labor costs.

Small firms show higher flexibility as well in making decisions for labor cost cut in addition to price reduction for survival. Also, it is easier for small firms to adopt resilience strategies such as product diversification of the work place for lower rental after the crisis.

In a later interview, the owner said that business has gradually recovered after the peak of the pandemic outbreak. Around May 2020, the firm achieved around $70 \%$ of the sales revenue before the outbreak. However, the owner still worries about the future of his small business due to the general contraction of consumers in purchasing items other than daily necessities as sports equipment.

\section{Reports and data analysis}

\section{1- Large impact on entrepreneurial small startups}

A survey that was performed on 2170 businesses in 121 countries revealed that the majority of small startups have been strongly affected by the pandemic and the taken measurement for its containment (ITC calculations, 2020) Smaller firms are the 
mostly affected by covid-19 than the larger ones. Nearly $60 \%$ of the smaller and micro companies reported having their business operation strongly affected by the crises compared to $40 \%$ for large firms. (Figure1)

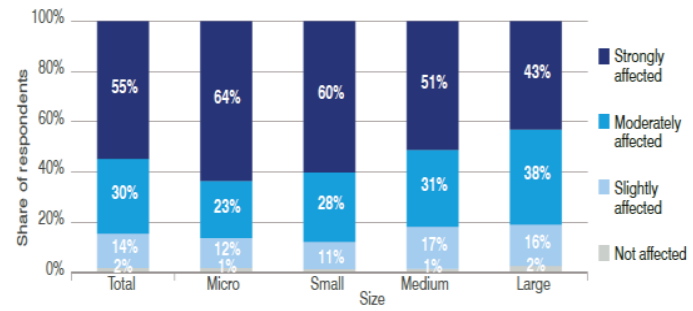

Figure 1- Smaller companies see larger impact from COVID-19

\section{2- Covid-19 impact according to the sector}

The impact of the crisis varies in correspondence to the sector. The companies that were operating in services are the most affected by COVID-19 (Fig 2), with the biggest impact reported by those in accommodation and food services.

Next in terms of severity were non-food manufacturing; retail and wholesale; and travel and transport. Micro, small and medium-sized enterprises are overrepresented in most of these sectors.

In accommodation and food services, $76 \%$ of businesses said their operations were strongly affected by COVID-19 as a result of partial and full lockdown (Figure 2). Nearly more than three quarters of the companies in this sector have experienced a big decline in their sales.

On the other hand, another survey that was performed on 2079 businesses in 121 countries showed that the pandemic has presented an opportunity for some manufacturing companies. About $10 \%$ of companies in agri-food processing experienced a significant rise in sales due to COVID-19. 


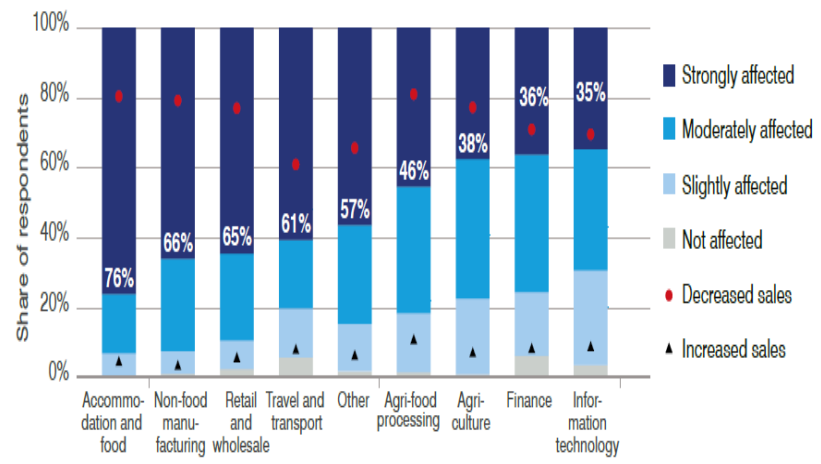

Figure 2- Sectoral impact of COVID-19

\section{3- Different impact on different entrepreneurs}

Women-led firms reported being more heavily impacted by COVID-19 than men-led ones. According to a survey that was performed on 2109 businesses in 120 countries, nearly $64 \%$ of women-led companies announced that their business operations were hugely affected by the virus outbreak, in comparison with $52 \%$ for firms that were led by men (Figure 3). This suggests that women-led startup firms could be more sensitive to crises or have less options for support.

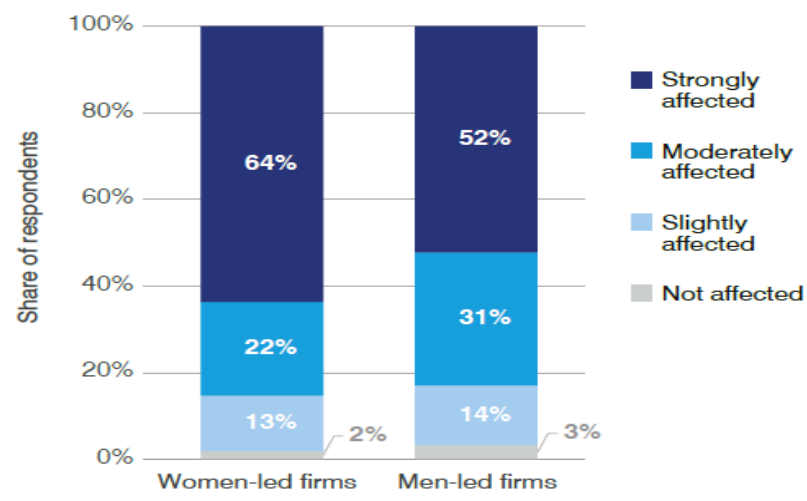

Figure 3- Shows that women firms are the most affected 


\section{4- Shutdown impact on small and youth-led startup firms}

Entrepreneurial small startups usually face more aggressive e resource constraints than larger companies and therefore they find it harder to survive when negatively affected by the COVID-19 outbreak crisis. About one-fifth (21\%) of entrepreneurial startups reported that they risked permanent shut down within a period of 3 months. They emphasized the urge for quick government action to help some firms (Figure 4). Youth-led firms were also at higher risk of permanently closing their business. About $26 \%$ of youth-led firms reported that they risked shutting down permanently within three months, compared with $18 \%$ for non-youth-led firms (Figure 4).

The majority of the entrepreneurial startups are led by young entrepreneurs, which reveals the difficulty the face in order to cope to turmoil. Possible reasons may include lack of experience, diversification, access to resources and social networks.

It is found that it was easier for young entrepreneurs, on average, to access the data and benefits from pandemic-related government assistance programs compared to the older entrepreneurs.

When they were asked what the government could do to help, young entrepreneurs confirmed support in the short term for cost reduction such as employment programs and support to self-employed people.

\section{Informal businesses often lack safety net}

Most of the small entrepreneurial startups are not registered with national authorities and have few financial cash to tide them over and found it hard to pay their workers and employees, many of whom depend on daily wages for their basic needs.

The loss of the income they deliver has exposed a lot of workers to hunger, precariousness and mass migration, because the workers returned to their home villages trying to search for social support net. 


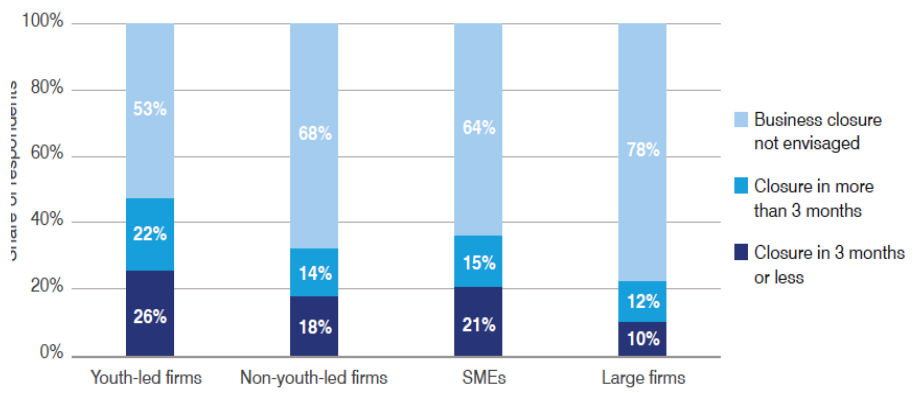

Figure 4- SMEs and youth-led firms are at higher risk of permanently shutting down in coming months

\section{Literature Review}

The search was done through reviewing available literature and documents from PubMed and Cohort studies using search keys such as "Impact of covid-19 on economy", "Pandemic effects on business".

The term start-ups refer to a company in the first stage of its operations. Usually, these small companies face challenges and they struggle for existence. These companies generally start with high costs and limited revenue and usually look for capital from different of sources such as venture capitalists (Salamzadeh \& Aidin, 2015). Small enterprises are crucial for the development of the local economy, in particular, in creating new employment opportunities, assistance of economic growth, alleviating poverty, generation of jobs and enhancement in the standard of living and quality of life (Abudul, 2018).

A survey that was conducted by Bartik, Bertrand, Cullen, Gbeser, Luca, and Stanton (2020), on more than 580 small enterprises between the date of March 28 and April 4, 2020, showed that there were massive layoffs, termination of business, various beliefs developed about the how the duration of the COVID linked disruptions, numerous businesses are on the brink financially, and the majority of businesses planned to seek funding. 
Another impact of COVID-19 is to preserve employee's safety and decreasing their exposure to COVID-19 transmission in the workplace. (KPMG, 2020 was switching to digital connection for schooling, higher education, business conferences and meetings, health consultations and online visits, online shopping, and cultural events (Phillipson et al., 2020).

\section{1- The most affected sectors from Covid-19}

The effects of COVID-19 are felt disproportionately across an economy and while some sectors may benefit financially from the current situation, others will suffer great losses (Seetharaman P., 2020). Those countries with more service-oriented economies will be more negatively affected, and suffer larger negative employment effects (Fernandes, Nuno, 2020). Sectors that were hit hard by the pandemic are: Hospitality-related sectors, tourism, airlines have had grounded fleets. Additionally, holidays have been cancelled and hotels have been closed. Also, no doubt that the world stock market has also suffered dramatically since the outbreak of COVID-19.

The oil gas and coal businesses have seen huge losses as well (50\% below the start-of year prices), driven by a fall in the price of oil and a reduction in consumption (Fernandes, 2020).

\section{2- Reasons why startups are mostly affected}

Startup entrepreneurship go through multiple phases during its lifecycle. Each phase has its specifics and conditions as it depends on culture, jurisdiction and sector, etc. (Salamzadeh, Aidin \& Kawamorita, et al, 2015) However, the majority of startups are in their early phases and funded by the founders, friends/family or could also be Crowdfunding.

The graphic below exhibits the various phases of the startups. Some researchers suggest that the "valley of death" is a bit longer but in principle this is how most describing the lifecycle of a startup. 


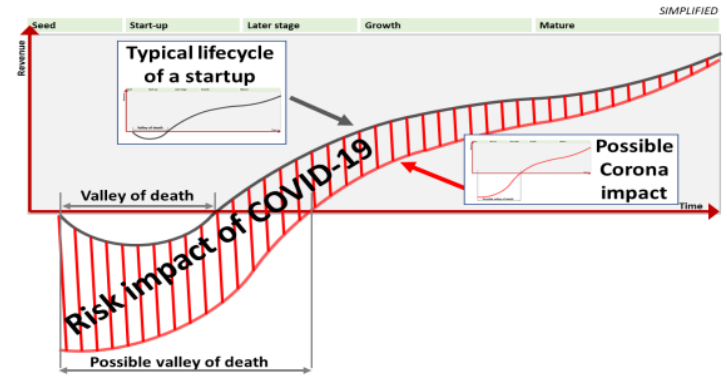

Figure 5- Most startups are vulnerable at early stages

\section{3- Responses of small startups to the Covid-19}

Some innovative small companies have responded rapidly and with flexibly to the pandemic, and have been critical in assisting many countries to, move towards fullydigital work, education, and health services in addition to providing innovations in medical goods and services (Bartik, Bertrand, Cullen, et al, 2020). A few examples include: commercial products adaptation such as snorkeling masks that could be used for oxygen provision in healthcare centers, launching digital health services, such as COVID-19 trackers. In addition to remote patient monitoring and consultations tools, applying a "no-contact" food delivery; and offering artificial intelligence answers for researchers and scientists, remote working tools like 'working from home', and online education and entertainment, that are mostly offered free of charge.

On the other hand, the majority of the existing start-ups face significant challenges, as they are more vulnerable than older and larger incumbents to the shocks brought by COVID-19. (Brown R, Rocha A, 2020).

\section{4- Companies closure}

An early assessment based on data for the United Kingdom states that startup firms that range between one and five years old, 
Account for three quarters of the $70 \%$ rise in the number of company dissolutions in March 2020 compared to March 2019 (Prashar; Ri, Hart, et al, 2020).

The following graphs illustrate the number of dissolved companies in the UK by regions (Figure 6) and the later graph (Figure 7) shows the number of dissolved firms in March 2020 in contrast to March 2019.

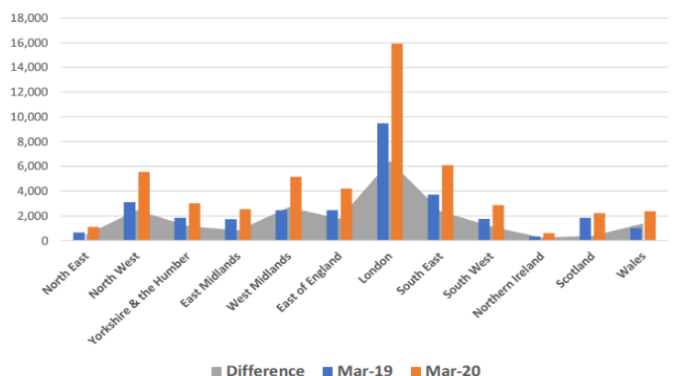

Figure 6- Number of dissolved firms by region: March 2019 \& March 2020

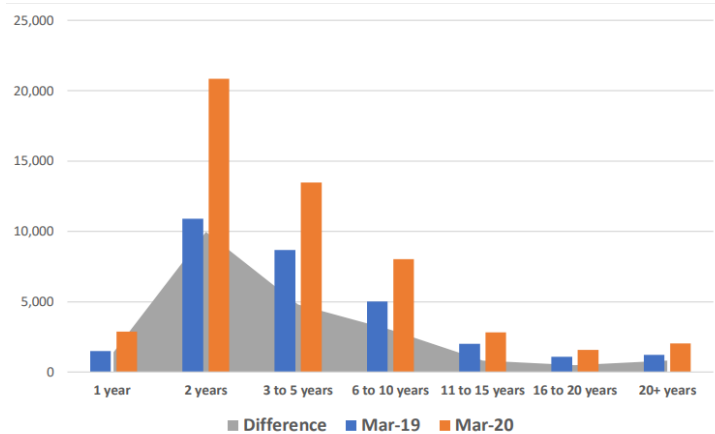

Figure 7- Number of dissolved firms by age of firm: March 2019 and March 2020 


\section{5- Four phases of pandemic impact}

As entrepreneurial small businesses face the COVID-19 challenges, they pass through four phases, whether in successively or simultaneously (Figure 8).

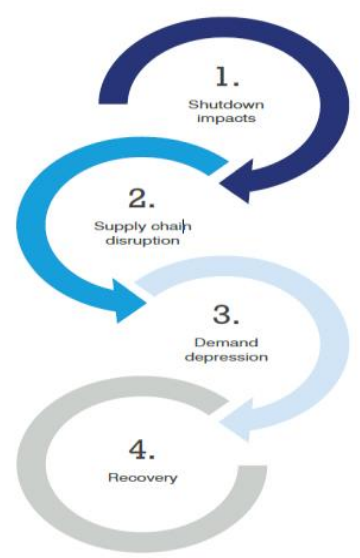

Figure 8

1. Shutdown impacts have impacted regions and countries and the pandemic forced the governments to implement measures of shutting down economic activity. (Hassan, Absar \& Fahad, 2020). Governments in the affected countries have focused to keep entrepreneurial small startups relating to affected sectors afloat in the short run.

2. Supply chain: The pandemic-induced lockdowns in China, the European Union (EU) and the USA, known as G3 have had major effects on production in addition to imports and exports (Evenett, S., 2020).

Halts and delay in production in the affected economies decreased the available inputs for global supply chains. Entrepreneurial small startups in other places in the world in the supply affected countries have seen their declines in orders as demand declined.

3. Demand depression has appeared first in pandemic impacted countries, where confinement decreased the sales to consumers and businesses. Despite that, when the health emergency started to ease, business investment can still remain low due to shortage and run-down savings. 
Confidence may decrease, credits could get overstretched, and bankruptcies among entrepreneurial small startups may follow (He, H., \& Harris, et al, 2020).

4. Recovery The development of business recovery in every country relies upon how the health situation advances and timing of the original suppression of demand.

In the weeks after lockdowns cease, economic activity is probably to rebound dramatically as people go back to purchasing the products they have missed from their favorite small businesses. However, the period of lockdown may permanently alter the production and demand processes. The pandemic is reshaping the economy. This 'new normal' can make recovery a more of a challenge to some, and easier for others (Mandel, A., Veetil, 2020).

\section{6- Surviving the Pandemic}

Most of the entrepreneurial small businesses will need to make extreme changes to survive the pandemic. The theme is protecting the health of their employees and customers, applying new business models, adjusting staffing models, improving labor practices and investing in technology and talents. However, these small businesses will need to make these changes at greater relative costs and less working capital. In addition, that they have little room for technology investments due to their low financial resilience.

Recovery will take time. After the year 2008 recession, larger companies took about four years to recover their precrisis contribution to GDP, while smaller ones took six years in average to recover 
According to McKinsey Global Institute and Oxford Economics, across all businesses, it could take five years or longer to recover from the pandemic, while it could take even longer for small businesses or may never reopen again. The following figure (Figure 9) illustrates the assumed number of years taken by various sectors in order to get back to the contribution they provided to the GDP before COVID-19.

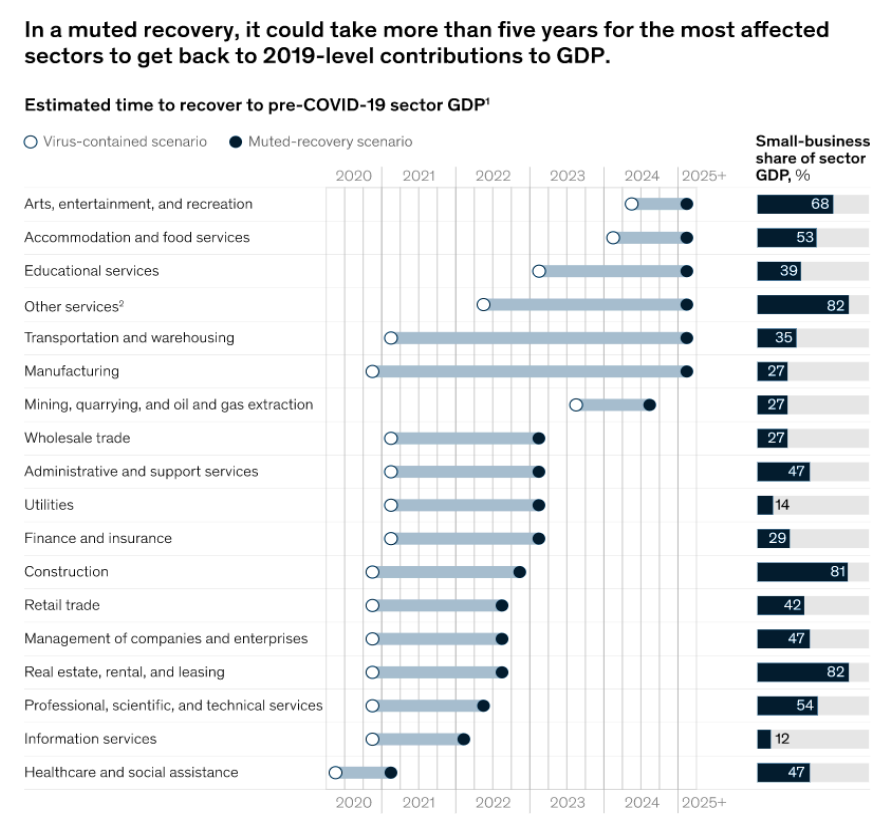

Figure 9- Years taken by sectors to gain their recovery

Also, an effective collaboration from governments, international organizations and supply chain stakeholders helps small startups to continue despite the crises.

An ITC COVID-19 business survey that was performed on 2,458 businesses in 125 countries revealed that small startup companies prefer certain type of support from their governments such as temporary tax relief, tax waivers, financial programs and cash transfer facilities. 


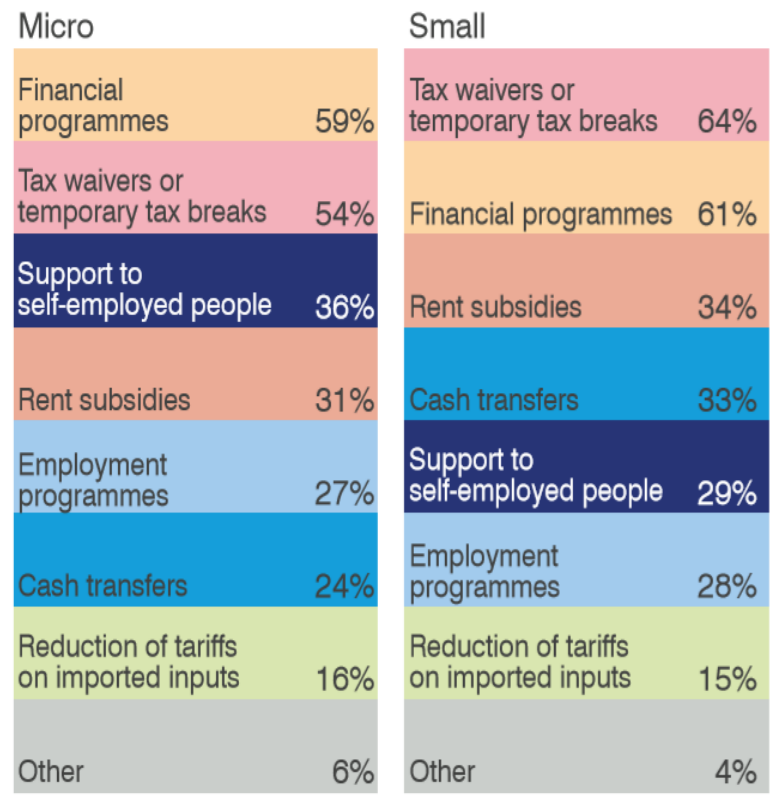

Figure 10- shows that most firms prefer financial programs and tax waivers.

Trade finance can assist cash-strapped small businesses maintain their export clients, and is specifically suitable for firms that export to compensate for lower local demand. For instance, the Export Credit Bank of Turkey stretched its rediscount credit terms to 2 years and extended its credit repayment periods by 2 to 6 months.

For companies to benefit from the government's assistance programs, access of information is important. However, approximately $60 \%$ of the micro enterprises reported difficulty to obtain information about COVID-19 assistance programs from the government compared with $42 \%$ of the larger companies.

One of the most common method to survive COVID-19 was to reduce the employment temporarily and stepping up online sales. However, smaller enterprises and new startups are less capable of working from home than larger companies.

The survival of US small businesses across the economy will require new business models and technology solutions that few have the resources to finance. 
The COVID-19 crisis has exposed financial frailties that have built over time, and the next normal could impose additional burdens. Adapting to such challenges will require that small businesses find new business and operating models and accelerate the adoption of new technologies. But those solutions will not be easy and will require an economy-wide effort to provide financing, restore demand, and improve small businesses' capability and resilience.

\section{7-Preparedness}

The future of entrepreneurial startups depends on how well the enterprise is prepared for crises.

The majority of the entrepreneurial small startups struggle in times of crises and are usually the least prepared of all companies. This is due to their limited capacities and resources that could allow them to prepare and cope with changes caused by crises like COVID-19 outbreak.

During the pandemic, the infrastructure of the small firm remains in place but many employees and workers have the unwillingness to travel or even enter the work place. Thus, a continuity plan such as allowing employees to work from home is needed in order to keep the business going.

A study that tests 136 small entrepreneurial businesses in Thailand from the manufacturing, wholesale and retail to management and supportive services sectors. Outcomes from their qualitative study suggested that despite the fact that there is substantial small startup businesses disaster experience and skills, in general, small enterprises preparedness for business continuity is mostly limited or remains at low levels. (Kato and Charoenrat, 2018)

Small enterprises working on a large scale or for a longer period of times are more likely to be prepared for crises and are aware of business continuity and training requirements. 
A business continuity plan includes enabling employees to work from home, paid sick leave for staff, providing a seasonal flu vaccine to the employees and having personal protective equipment (PPE) in place to health care personnel.

\section{8-Four main characteristics of the 'new normal'}

The small and new enterprises will need to get involved in the new reality which is emphasizing on resilience to shocks, implement digitalization opportunities, sustainability and inclusiveness (Adams, P., 2020).

\section{a-Resilience}

It can strengthen their ability to ride out crises and reduce bankruptcy. One example for resilience is diversification, which allows small enterprises to establish suppliers and buyers to turn to if one part of the business is exposed to crises. Diversification is an important tool for risk management strategies that fits production, sales and purchasing. Another example would be manufacturing different products to ensure income fluidity even if the output or sales of one item collapses.

At the same time, having multiple suppliers is a must to increase the chances of production continuity no matter what the condition is. Also, selling to different buyers through variable channels ensures that some of the markets stays available even if the others shut down.

Saving profits is a good mean to provide a buffer in hard times plus it ensures additional financial investments in other technologies and skills that are important for innovation and to cope with any sudden changes like what happened with the COVID19. Small entrepreneurial startups could connect to business support organizations, industry associations and other representatives in their business ecosystem to bolster their ability to adapt with the situation. 
Building collaborative platforms among local industry actors for collecting data, communicating and solving problems facilitates the creation of an ecosystem and social forum where the participants could plan crisis responses and help one another.

\section{b- Digital}

During the lockdown, the whole or part of the businesses turned to digital platforms which kept the world going in the first quarter of 2020.

Therefore, small startups should enhance their digital abilities from now and on to be prepared for any changes in the future. (WTO, 2020).

A small Ghanaian cosmetics business, for example, reported that before the COVID19 started, $95 \%$ of sales were made through in person purchases, during the shutdown, online sales swelled, making the business to stay afloat.

However, small startup enterprises may face several issues concerning digitalization such as, entrepreneurial startups operating in countries that don't have local data centers, data security is not guaranteed and business data can be attacked by hackers and in countries that aren't backed up by strong institutional support and regulations, data can be misused (McDonald, S., 2020) and unstable internet connection. Thus, it is of a great importance to provide assistance to enhance the reliability and quality of local internet connections in developing economies as well as extend internet connection rate and levels of computing literacy. This allows small companies to sell to global markets. Platforms will allow small entrepreneurial startups to reduce the costs related to logistics and accessing knowledge through shared expertise.

\section{c- Inclusive}

The most sustainable solution is maintaining access to good and secure jobs. Entrepreneurial small firms account for about $70 \%$ of jobs around the world. They employ a disproportionate share of disadvantaged groups, such as less qualified workers, women and young people. Prior COVID-19, small enterprises and small firms were expected to generate 600 million new jobs by the year 2030 (TC, 2019a). 


$$
\text { الهجلة الدولية لنشر البحوث والدراسات }
$$

Therefore, the preserving businesses run by the small companies is a necessary, otherwise, it will be impossible to get back on track to achieve the Sustainable Development Goals by the year 2030. Efforts should be made by policymakers to support the small firms and their employees.

\section{d-Sustainable}

It is important to sustain the health and the wellbeing of the employees as the pandemic subsides. Sustainability is vital in post pandemic global economy and retrofitting for COVID-19 sanitary requirements.

\section{Conclusion}

Entrepreneurial practices of small startups have been hugely impacted by COVID-19. Some of these small startups have closed temporarily, while others went out of business. Small firms have reduced the number of the working employees and reduced wages. The majority suffered financial loss and decreased in sales and productivity. Enterprises working in education and training implemented online learning and others permitted working from home if available. The most affected sectors are the tourism and airlines especially during the lockdown period.

It was found that women were more affected by the pandemic than men and younger entrepreneurs were struggling more than elder ones due to the lack of expertise and limited skills.

Other small enterprises witnessed huge profits due to the new market needs and these include small firms operating in manufacturing mask, face shields and sanitary items. It is possible to recover the pandemic, however it will take some time. It all depends on the preparedness and the resilience of the company and how well it uses technology and get benefits from the support offered by their government. 


\section{References}

1. Abdul, O. E. (2018). Entrepreneurial skills and growth of Small and Medium Enterprise (SMEs): A comparative analysis of Nigerian entrepreneurs and Minority entrepreneurs in the UK. International Journal of Academic Research in Business and Social Sciences, 8(5), 27-46.

2. Adams, P. (2020, April 14). Re-thinking globalization with Ian Goldin. ABC. Financial Times. (2020, April 3).

3. Alves, Jose \& Osorio, Arturo \& Guo, Chun \& Khong, Yeung. (2019). Cross border entrepreneurship: Macau, Zhuhai, and Hengqin.

4. Bartik, A., Cullen, Z., Bertrand, M., Glaeser, E. L., Luca, M., \& Stanton, C. (2020). How are small businesses adjusting to COVID-19? Early evidence from a survey. SSRN Electronic Journal.

5. Brown R, Rocha A, Cowling M. Financing entrepreneurship in times of crisis: Exploring the impact of COVID-19 on the market for entrepreneurial finance in the United Kingdom. International Small Business Journal. 2020;38(5):380-390.

6. Evenett, S. (2020), "Tackling COVID-19 Together", Global Trade Alert, University of St. Gallen, Switzerland.

7. Fernandes, N. (2020). Economic effects of coronavirus outbreak (COVID-19) on the world economy. SSRN Electronic Journal.

8. Haltiwanger J, Jarmin RS, Kulick R, et al. (2016) High growth young firms: Contribution to job, output, and productivity growth. In: Haltiwanger J, Hurst E, Miranda J, et al. (eds) Measuring Entrepreneurial Businesses: Current Knowledge and Challenges. Chicago, IL: University of Chicago Press, pp.11-62

9. Hassan, Absar \& Fahad, Shah \& Naushad, Mahnoor. (2020). Factors Affecting Tourism Industry and Its Impacts on Global Economy of the World. SSRN Electronic Journal. 10.2139/ssrn.3559353. 


$$
\text { المجلة الدولية لنشر البحوث والدراسات }
$$

10. He, H., \& Harris, L. (2020). The impact of Covid-19 pandemic on corporate social responsibility and marketing philosophy. Journal of business research, 116, 176182.

11. ITC calculations based on ITC COVID-19 Business Impact Survey. Data collected 21 April - 2 June 2020.

12. ITC. (2019a). SME Competitiveness Outlook 2019: Big money for small business-Financing the Sustainable Development Goals (SME Competitiveness Outlook). International Trade Centre

13. Kato, M. and Charoenrat, T. (2018), "Business continuity management of small and medium sized enterprises: Evidence from Thailand", International Journal of Disaster Risk Reduction, Vol. 27, pp. 577-587.

14. Mandel, A., \& Veetil, V. (2020). The economic cost of COVID lockdowns: An out-of-Equilibrium analysis. Economics of Disasters and Climate Change, 4(3), $431-451$

15. McDonald, S. (2020, 30 March). The Digital Response to the Outbreak of COVID-19. Centre for International Governance Innovation.

16. Phillipson, J., Gorton, M., Turner, R. Shucksmit, H. M., Aitken-McDermott, K., Area, F., Cowie, P., Hubbard, C., Maioli, S., McAreavey, R., Souza-Monteiro, D., Newbery, R., Panzone, L., Rowe, F. and Shortall, S. (2020). The COVID-19 pandemic and its implications for rural economies. Sustainability, 12(3973), 2-9.

17. Prashar, N., Hart, M., \& Ri, A. (2020). From the cabinet of curiosities: The misdirection of research and policy debates on small firm growth. International Small Business Journal: Researching Entrepreneurship

18. Salamzadeh, Aidin \& Kawamorita, Hiroko. (2015). Startup Companies: Life Cycle and Challenges. 10.13140/RG.2.1.3624.8167.

19. WTO. (2020, April 8). Trade set to plunge as COVID-19 pandemic upends global economy. World Trade Organization Trade Forecast.

\section{Doi: $\underline{\text { doi.org/10.52133/ijrsp.v2.18.14 }}$}

